\title{
Breeding persistence of Slavonian Grebe (Podiceps auritus) at long-term monitoring sites: predictors of a steep decline at the northern European range limit
}

\author{
J. Stien ${ }^{1}$ K. B. Strann ${ }^{2}$ J. U. Jepsen ${ }^{2} \cdot$ V. Frivoll ${ }^{2}$ R. A. Ims ${ }^{1}$
}

Received: 30 January 2015/Revised: 17 May 2015/Accepted: 28 May 2015/Published online: 10 June 2015

(C) The Author(s) 2015. This article is published with open access at Springerlink.com

\begin{abstract}
The Slavonian Grebe (Podiceps auritus) has its European northern range limit in northern Norway, and is a species of national conservation concern due to its small population size and unknown population trend. Long-term monitoring at the range limit suggests breeding site use is in decline. We used annual occupancy data from 104 breeding lakes monitored since 1991 in northern Norway to investigate correlates of change in occupancy. Persistence was $100 \%$ until 1999 , but thereafter decreased to $25 \%$ (26 lakes with breeding pairs). A particularly steep decrease occurred between 2010 and 2012. Persistence increased with the number of pairs present in each lake in the initial monitoring year of 1991. The number of grebe pairs also decreased in the lakes that had continuous breeding persistence over the entire 22-year monitoring period, suggesting that a large-scale factor caused the population decline. Over the last year of the monitoring series, lake
\end{abstract}

Communicated by C. Barbraud.

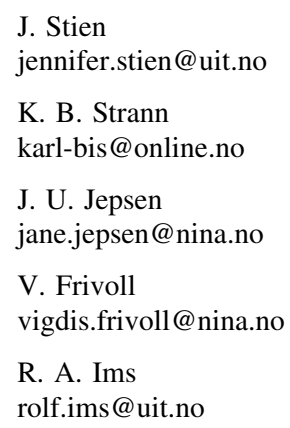

1 Department of Arctic and Marine Biology, UiT-The Arctic University of Norway, 9037 Troms $\varnothing$, Norway

2 Norwegian Institute for Nature Research (NINA), Framsenteret, Post Box 6606 Langnes, 9296 Troms $\emptyset$, Norway altitude was negatively related to the probability of persistence, indicative that locally harsh climate played some role in breeding distribution. The temporal pattern of persistence was not related to mean winter temperature at the breeding sites; however, the decrease between 2010 and 2011 coincided with a late ice melt in 2010. Monitoring that includes a larger area of the species' range is required to conclude whether the observed decline can indicate an overall decline in population size, or range fluctuations at the edge of the species' range. However, investigating the processes that determine population range borders can give insights into important limiting factors pertinent to the conservation of species in the long term.

Keywords Range change - Red list - Conservation . Proportional hazard models · Long-term monitoring

\section{Zusammenfassung}

Persistenz des Ohrentauchers (Podiceps auritus) an längerfristig kontrollierten Brutplätzen: Anzeichen eines deutlichen Rückgangs an der nordeuropäischen Verbreitungsgrenze

Der Ohrentaucher (Podiceps auritus) hat seine nordeuropäische Verbreitungsgrenze in Nord-Norwegen und gilt dort aufgrund geringer Populationsgröße und unbekanntem Populationstrend als Art mit nationalem Schutzbedarf. Langzeituntersuchungen an der Verbreitungsgrenze sprechen dafür, dass die Besetzung der Brutplätze zurückgeht. Anhand von jährlichen Anwesenheitsdaten von 104 Brutseen in Nord-Norwegen, die seit 1991 regelmäßig kontrolliert wurden, untersuchten wir die Zusammenhänge der Veränderungen in der Besetzung. Bis 1999 lag die Persistenz bei $100 \%$, fiel danach aber auf $25 \%$ ab (26 Seen mit 
Brutpaaren). Ein besonders deutlicher Abfall ereignete sich zwischen 2010 und 2012. Die Persistenz nahm mit der Anzahl anwesender Brutpaare an einem See im ersten Beobachtungsjahr 1991 zu. Auch in Seen mit kontinuierlicher Brutpersistenz während des gesamten 22-jährigen Untersuchungszeitraumes nahm die Anzahl an Taucherpaaren ab, was darauf hindeutet, dass der Populationsschwund auf einen großflächig wirksamen Faktor zurückzuführen ist. Im letzten Jahr des Untersuchungszeitraumes stand die Höhenlage des Sees in negativem Bezug zur Wahrscheinlichkeit der Persistenz, was dafür spricht, dass ein raues Ortsklima eine Rolle bei der Brutverbreitung spielte. Das zeitliche Muster der Persistenz stand in keinem Bezug zur mittleren Wintertemperatur an den Brutplätzen, allerdings fiel die Abnahme zwischen 2010 und 2012 mit spät einsetzendem Tauwetter in 2010 zusammen. Untersuchungsprogramme, die einen größeren Bereich des Verbreitungsgebietes der Art abdecken, sind vonnöten, um entscheiden zu können, ob die beobachtete Abnahme ein Hinweis auf einen allgemeinen Abfall der Populationsgröße ist oder ob es sich um Fluktuationen im Verlauf der Verbreitungsgebietsgrenze handelt. Studien der Prozesse, welche die Verbreitungsgrenzen einer Population bestimmen, können allerdings auch Einblicke zu wichtigen limitierenden Faktoren liefern, welche für den langfristigen Artenschutz von Belang sind.

\section{Introduction}

Identification and management of species of conservation concern is hampered by a lack of knowledge about the population trends of the target species. Knowledge is often dependent on species popularity, with both knowledge of population trends and conservation management being most prevalent for birds, butterflies and mammals and less so for other insects and amphibians (Lecis and Norris 2004; van Swaay et al. 2008). Even for charismatic species, monitoring to capture spatial variation in population trends and ranges is often lacking. However, in recent years more robust monitoring programs have been established that allow estimation of change in state or continent-wide population ranges (e.g., Newson et al. 2005; van Swaay et al. 2008; Thomas 2010).

Site and/or habitat occupancy may vary temporally and spatially, with occupancy at range edges especially prone to change over time, as the ecological conditions may be suboptimal (White 2008; Sexton et al. 2009; Gilman et al. 2010; Rius and Darling 2014). In addition to physical limitations, range may be determined by distance from the original core site and local abundance (Lawton 1993). Thus, (sub-)populations at species range edges are often transitory (Lawton 1993), existing in metapopulations or source-sink populations (Hanski and Gaggiotti 2004) that can be reduced to extinction state when conditions become less favourable.

Investigating causes of change in species range has received much attention in the scientific literature, particularly with respect to climate change and its implications for vulnerable species (e.g., Chen et al. 2011; McClure et al. 2012). Physical factors (e.g., climate) are recognised as being the principal drivers of species ranges at regional and larger scales, whereas biological interactions are more important at local scales (Araújo and Luoto 2007). In addition, physical factors are considered to be of primary importance at the northern edge of species ranges (e.g., Chen et al. 2011), although some advocates of climatic envelope models state the need for the inclusion of demographic factors such as dispersal and intra/interspecific interactions (e.g., Davis et al. 1998). Demographic factors may be of particular relevance for species characteristically breeding in small numbers in discrete habitat patches across their range, with the small unit size making patches prone to extinction due to founder effects and demographic stochasticity (Traill et al. 2007; Moran and Alexander 2014; Rius and Darling 2014). Species that migrate between breeding and non-breeding grounds may moderate the risk of patch extinction by forming seasonal re-colonising waves (Moran and Alexander 2014). As such, migratory species have the potential to exist in suboptimal breeding areas.

Empirical studies involving both physical and biotic correlates of range change can result in important insights into decisive factors underlying range shift (e.g., Lecis and Norris 2003; McClure et al. 2012), and are therefore an essential component for guiding effective management for species of conservation concern. Much data is readily available from existing databases regarding site characteristics of high biological significance for species. Combined with existing temporal site persistence data, this can be used to investigate decisive factors for range shifts.

The Slavonian Grebe (Podiceps auritus) is a species of national conservation concern in Norway (Kålås and Viken 2006; Direktoratet for Naturforvaltning 2009); however, there is currently no systematic monitoring at the national scale (Øien and Aarvak 2008). The Slavonian Grebe is a seasonally migratory species, overwintering in coastal regions and breeding in small numbers, mostly on small inland lakes (Faaborg 1976; Sonntag et al. 2009; Summers et al. 2011). Present in Northern Norway at the northern end of its European range for over a century, the species experienced an apparent increase in numbers between the 1970s and 1990s (Fjeldså 1973a; Strann and Frivoll 2010). However, monitoring of active northern breeding sites from the 1990's to the present shows a decrease in the 
number of pairs and in site use (Strann et al. 2014). At the southern end of its Norwegian range, it is becoming more abundant and it appears to be spreading southwards (Øien and Aarvak 2008). Proposed but largely untested factors responsible for the decline of the Slavonian Grebe have been identified in an action plan for the species (Direktoratet for naturforvaltning 2009), and include predation by mink Neovison vison (Stien and Ims 2015), predation by corvids and food resource competition with fish. However, additional factors, including several habitat characteristics expected to have biological significance as drivers of site persistence and indeed range change, were not included.

We investigated the breeding site persistence of the Slavonian Grebe at 104 lakes at the northern edge of its population range between 1991 and 2012, in order to evaluate the relationship between pertinent physical and biological factors and the population decline. We expected lakes with small populations, unproductive habitat and harsh climate to be more likely to become disused as breeding areas. We discuss the implications from the study for management of this targeted species.

\section{Materials and methods}

\section{Study species and area}

\section{Study species}

The Slavonian Grebe, hereafter referred to as grebe, has a circumpolar distribution mainly at $50-65^{\circ} \mathrm{N}$ in the boreal climatic zone, breeding in North America, mainland Europe, Iceland, the Faroes and Scotland (Bird Life International 2011). In Norway, the species extends between $60^{\circ} 52^{\prime}$ and $69^{\circ} 30^{\prime}$, and so forms one of the most northerly ranges for the species internationally (Fjeldså 1973a; Fournier and Hines 1999). Occasional breeding has been recorded further north in Norway, in eastern Finnmark and adjacent districts in Finland and Kola Peninsula (Fjeldså 1973a). The populations of Norway, Iceland and Scotland are described as a subspecies P.a. arcticus (Fjeldså 1973a).

The grebe spends most of the year in marine habitat, but migrates inland to breed between May and September. Breeding can occur in both freshwater and brackish water and in a wide range of lake sizes, with sites $<10$ ha common in north America and the Baltic, and a larger range of site areas used in northern Norway and Iceland (Fjeldså 1973b; Faaborg 1976; Ulfvens 1988; Ewing et al. 2013). Sites commonly have between one and two pairs and seldom more than 20 pairs per lake (Fjeldså 1973c; Faaborg 1976). In Norway, winter habitat is in coastal archipelago and outer fjord systems (Fjeldså 2004; Strann and Frivoll 2010), with part of the population migrating as far south as the Scottish coast (Øien and Aarvak 2009). Inland observations during winter are rare and are normally before ice has formed on lakes or on ice-free lakes close to the coast (Cramp et al. 1977; Øien and Aarvak 2008). Onset of nest building is determined by ice melt and varies considerably with latitude, altitude and season (Cramp et al. 1977; Fjeldså 2004). Nests consist of floating rafts of dead plant material, constructed in shore vegetation. Diet during the breeding season consists mostly of fish by biomass, but also of aerial and aquatic invertebrates (Fjeldså 1973b; Dillon et al. 2010). Young and adults migrate to the coast in September.

The species has a circumpolar population of 140,000-1,100,000 individuals (Bird Life International 2011). The general trend for the population is declining, e.g., $75 \%$ decline in North America over the last 40 years (Bird Life International 2011), but due to the size and geographical extent of the population, the species is categorised as of 'least concern' on the International Union for Conservation of Nature (IUCN)'s red list (Bird Life International 2004). In Western Europe and Scandinavia, historical records indicate a range expansion westward into southern and middle Sweden during the late 1800's and early 1900's. The populations in northern Norway and Iceland have been in existence for at least two centuries, while the population in Scotland established itself during the first half of the 20th century (Fjeldså 1973a; Douhan 1998). In Norway (Fig. 1, area A), historical records indicate that the core area in the 1970's was estimated to be c. 400 pairs (Fjeldså 1980).

Although no systematic monitoring of grebe occurs on a national scale, regional scale monitoring of core sites in Troms and bordering Nordland reveals a decrease in the use of breeding sites compared to when monitoring began in 1991 (Strann and Frivoll 2010; Strann et al. 2014). National declines have been reported in neighbouring countries, with an estimated $54 \%$ decline between 1972 and 1996 in Sweden (Douhan 1998) and a strong negative population change index since 1997 in Finland (Pöysä et al. 2013). In Sweden, the population appears to have increased again, and in 2011 was estimated to be close to the 1972 estimate of 2200 pairs (Norevik 2014). This increase has been accompanied by an apparent eastward shift in its range away from inland areas to areas along the Swedish Baltic coast (Norevik 2014).

\section{Study area}

We report data from 104 study sites located in Troms and northern Nordland regions, between $68^{\circ} 30^{\prime}$ and $69^{\circ} 43^{\prime} \mathrm{N}$ and $16^{\circ} 39^{\prime}$ and $22^{\circ} 09^{\prime} \mathrm{E}$. Sites were chosen for monitoring annual breeding success, and were therefore all occupied in 1991. Six sites were omitted from the analysis as they had 


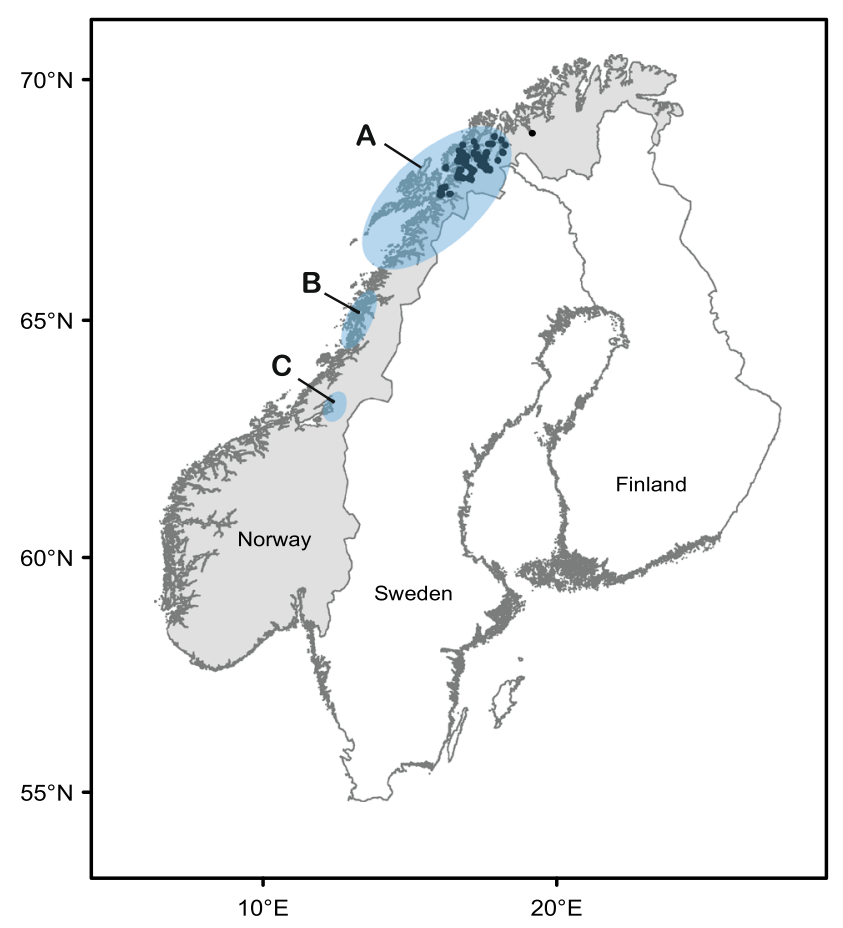

Fig. 1 The historical Norwegian distribution of the Slavonian Grebe between 1950 and 1970, adapted from Fjeldså (1973a), and the distribution for the present study between 1991 and 2012. The historical distribution is located in northern Nordland and Troms $(a)$, the Helgeland coast $(b)$, and North Trøndelag $(c)$, and the sites used in the present study are shown by dots

very different habitat characteristics than those of lakes; five occurred in "lombolas", which are small widenings of river sections, and one opened directly into the sea. The 104 study sites were all inland and fed by streams or rivers and/or had rivers as outflows. Average (mean) water body area was 93 ha (median 19.18, range $0.34-1521$ ha) and mean altitude was $90.98 \mathrm{~m}$ (median 91.00, range 0-269 m). Immediate surrounding vegetation was dominated by mosaics of mountain birch (Betula pubescens), Scots pine (Pinus sylvestris), mire, heath and grassland. Agricultural grassland also existed around some lowland lakes. Lake bedrock consisted of mostly calcareous rock types, including mica, mica slate, meta-sandstone and amphibolite, with smaller frequencies of marble rock types, including calcareous mica and marble. Granite rock types including dioritic to granitic rocks and conglomerate and breccia occurred less often. Lakes were mostly oligotrophic, with several mesotrophic and eutrophic lakes. Dominant shallow water vegetation included bottle sedge (Carex rostrata), and to a lesser extent, bogbean (Menyanthes trifoliata), and provided nesting habitat for the grebe. Lake vegetation was sparse in oligotrophic lakes, forming small pockets of nesting habitat, and was more or less continuous in eutrophic lakes, providing continuous nesting habitat around the lake edge perimeter. Mean distance from lake centroids to the nearest road, ranging from district to European road, was $0.53 \mathrm{~km}$ (median 0.44, range $0.25-1.99 \mathrm{~km}$ ).

\section{Data}

\section{Grebe monitoring}

Monitoring was based on two visits each year in the period 1991-2012. The first visit was around 22 June, roughly 3 weeks after ice melt and the second was between 10 and 20 July (exceptionally, the end of July). Number of nesting pairs, territorial pairs and non-territorial individuals were counted in both visits from standardised observation points using binoculars and telescope. The counts of nesting pairs were used in the analysis and were expressed as a single unit of observed number of breeding pairs per lake.

\section{Habitat}

Habitat variables were extracted using ArcMap 10.0. Lake bedrock was categorised into three bedrock categories, calcium, granite and marble, to reflect water $\mathrm{pH}$ and hence be a proxy for lake ecosystem productivity determining nesting habitat and food resource availability. The marble category was used where marble-derived bedrock was present, the calcium category where calcareous bedrock was present in the absence of marble, and the granite category where bedrock was derived of granite without the presence of marble or calcium. Vegetation around each lake was classified based on a national vegetation map developed from Landsat imagery (Satveg, Johansen 2009). From this map, the original 25 vegetated classes were grouped into six initial habitat types: coniferous forest, deciduous forest, mire, alpine, herb and agriculture, and further into three broad landscape types: forest, open lowlands (mires, herb and agriculture) and alpine. The proportions of the different habitat types were calculated in two buffers surrounding each lake with a radius of 100-200 m, respectively. Visual inspection of the resulting proportions revealed no difference between the two buffer radii, and a $100 \mathrm{~m}$ buffer was therefore chosen to represent the proportional coverage of habitat and landscape types around each lake. Proportion of agricultural land was used as a proxy of eutrophication, which has been shown to be associated with colonisation of previously unused breeding areas (Douhan 1998). Distance between individual lakes and the nearest road was used as a proxy of disturbance.

As no data existed for the date of ice melt of individual lakes, we explored the use of air surface temperature and snow depth data as possible proxies (Borgstrøm et al. 2010; Kvambekk and Melvold 2010; Godiksen et al. 2012). Values were extracted from national air temperature and 
snow depth models with a 1-km grid resolution (https:// met.no). Where lakes crossed two grid squares, the value from one of the grid squares was selected at random. Mean temperature and total cumulative positive temperature $\left({ }^{\circ} \mathrm{C}\right)$ were expressed as yearly mean and yearly summed temperature $>0{ }^{\circ} \mathrm{C}$ respectively, for time-dependent analysis (see below) and total mean and total positive cumulative temperature for the time-independent analysis. Snow depth was expressed as yearly mean snow depth or total mean snow depth. Exploration of three winter time periods, 1 November-31 May, 1 January-31 May and 1 April-30 June, indicated that ice melt was best indicated by positive cumulative temperature and that there was no statistical difference between time periods (AICc, Burnham and Anderson 2002). The period of January to the end of May was used with a sample size of 99 lakes for the timedependent analysis of ice melt, as five lakes shared meteorological data grid squares.

\section{Statistical analysis}

We used Cox proportional hazards models (R library survival) to estimate the instantaneous risk of individual lakes becoming disused as breeding lakes over the 22-year monitoring period. The model takes the form

$\log h_{\mathrm{i}}(t)=\alpha(t)+\beta_{1} x_{\mathrm{i} 1}+\beta_{2} x_{\mathrm{ik}}+\cdots+\beta_{\mathrm{k}} x_{\mathrm{ik}}$

where $h_{\mathrm{i}}(t)$ is the hazard function, i.e., the instantaneous risk of loss of breeding lake at time $t$, given that the survival to that time, $\alpha(t)$, is an unspecified baseline hazard function and $\beta_{\mathrm{k}} x_{\mathrm{ik}}$ are the covariates entered into the model linearly (Fox 2002).

The presence-absence records indicated that detection rates were very high, as continued presence were interrupted by one $(n=11)$ to two (non consecutive) years $(n=2)$ in only 13 of the 104 lakes. Thus, the detection rate could be assumed to be close to unity (and thus was omitted from the analysis), which allowed for more flexible and powerful analyses by semi-parametric Cox proportional hazards models (R library survival). For the 13 lakes with pseudo-extinctions, the intermittent zeros (absences) were replaced with ones (presence) in those data records.

The full model contained additive effects of the continuous predictors altitude, lake area, number of breeding pairs at $t_{0}$ (i.e. 1991), distance to nearest road (road) and proportion of agricultural land (vegetation) and the threelevel factor bedrock with classes marble, calcareous and granite. The number of breeding pairs was used as a proxy for susceptibility to demographic stochasticity, which could be expressed as total mean, total maximum and number at start of monitoring in $1991\left(t_{0}\right)$. These indices of local population size were highly correlated, but investigation showed that number of pairs at $t_{0}$ was the best predictor. Ice melt was initially explored as a time-dependent variable, but the coefficient estimate was not significant. Ice melt was therefore entered as a timeindependent variable in a time-independent Cox proportional hazard model. As ice melt and altitude were highly correlated, the two were entered in separate models. All continuous variables were transformed to centralise their distributions and increase linearity, with square root transformation for altitude, number of breeding pairs $\left(t_{0}\right)$, road and agricultural land. Lake area was log-transformed. Analyses were carried out in software package R (R Core Team 2014), and best model was chosen by AICc. Goodness of fit of the selected models were assessed by Chisquare test on Schoenfield residuals, and their predictive ability was assessed by AUC (Receiver Operating Curve) scores at a percentage scale (maximum predictability $=$ $100 \%)$.

\section{Results}

The model including effects of altitude, lake area and number of breeding pairs at $t_{0}$ best predicted the persistence of breeding sites. However, this model showed violation of the assumption of proportional hazards for both altitude (Schoenfield residuals $\chi^{2}=6.19, p=0.01$ ) and number of breeding pairs at $t_{0}$ (Schoenfield residuals $\left.\chi^{2}=10.56, p=0.0001\right)$. Examination of the residual plots suggested that the hazard ratios increased abruptly between 2011 and 2012 for these predictors. We therefore split the data into two groups to be analysed in separate models with the same covariates; the first model for the period 1991-2011 and the second for 2011-2012. As the second period had one time interval, the analysis could be simplified to a binary logistic regression of the probability of one further year persistence of those lakes with breeding pairs still present in 2011. The fit for proportional hazard model containing effects of altitude, lake area and number of breeding pairs at $t_{0}$ was good when leaving out the last year of the time series (2012) (Schoenfield residuals 1991-2012: $\chi^{2}=5.72, p=0.12$ ). Only the coefficient for the predictor number of pairs at $t_{0}$ was statistically significant (Fig. 2). The estimate of this coefficient shows that an additional increase of 1 in the square root of number of breeding pairs at time $t_{0}$ reduced the hazard rate for loss of breeding lake by $90.2 \%(\exp [-2.31]=0.098, p<0.001)$. The proportional hazard rate model for the period 1991-2011 explained $44 \%$ of the variation and had good predictive power with an area under the receiver operating curve (AUC) of $81 \%$ (95\% CI 71-89). Mean predicted probability of individual lake persistence after 21 years (in 2011) was 0.36 (95\% CI 0.28-0.47). The loss of breeding sites began after 8 years (1999) (Fig. 2), with a pronounced 
Fig. 2 Predictions (solid lines) of probability of grebe breeding persistence with $95 \% \mathrm{CI}$ (dotted lines) from the best model for Cox proportional hazard model for 104 lakes in Troms and northern Nordland for the period 1991-2011; a mean of all coefficient estimates, and predictions for different levels of $\mathbf{b}$ number of pairs $\left(\mathrm{t}_{0}\right)$, c lake altitude, and d lake area. $p$ values are derived from z-test of the coefficients of the predictor variables (a)

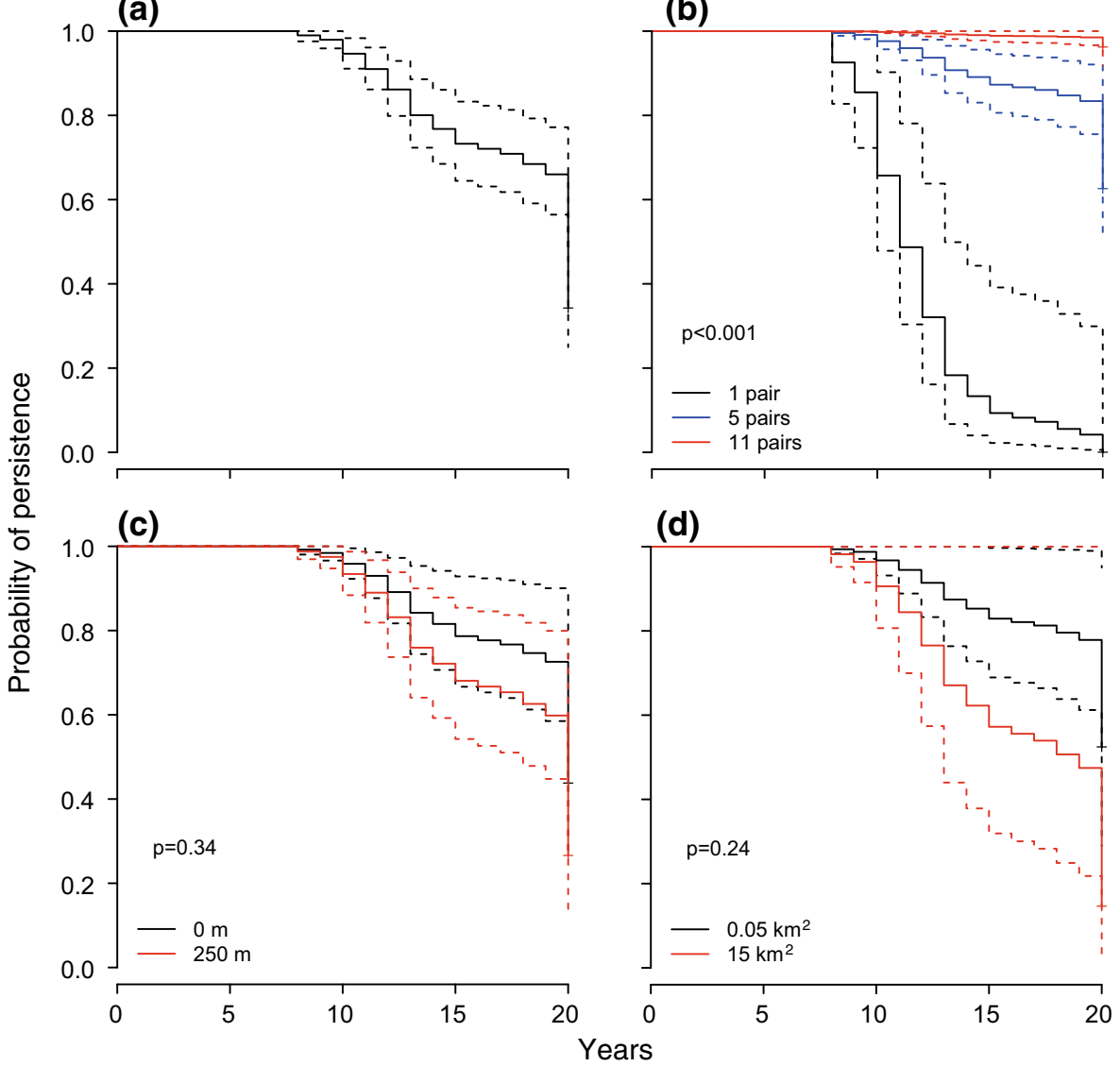

additional drop in the probability curve after 20 years (between 2010 and 2011). In the logistic regression model for the period 2011-2012, only the coefficient for altitude was significant $(-0.23 \pm 0.10, p=0.02$, area $=-0.20 \pm$ $0.28, p=0.48$, number of pairs at $t_{0}=-0.07 \pm 0.87$, $p=0.93$, df = 34; Fig. 3). Between 2011 and 2012, mean predicted probability of individual lake persistence decreased by $31.6 \%$.

None of the habitat variables except altitude and lake area predicted the persistence of grebe in individual lakes. There was a small significant negative correlation between number of breeders at $t_{0}$ and proportion of mire $(-0.27$, $p=0.005$ ), and a small significant positive correlation between number of breeders at $t_{0}$ and the proportion of herbs $(0.31, p=0.001)$, which to some extent might have concealed their effects. Goodness of fit test revealed that the overall model containing ice melt showed some indication of violation of the assumption of constant proportional hazard of predictor variables $\left(\chi^{2}=15.00\right.$, $p=0.03$ ), with both number of pairs at $t_{0}$ and ice melt showing indications of being non-proportional in predicting hazard rate $(p<0.05)$. As model selection using AICc showed no difference between the use of altitude or ice melt, altitude was used, enabling the use of all 104 sites in the analysis.

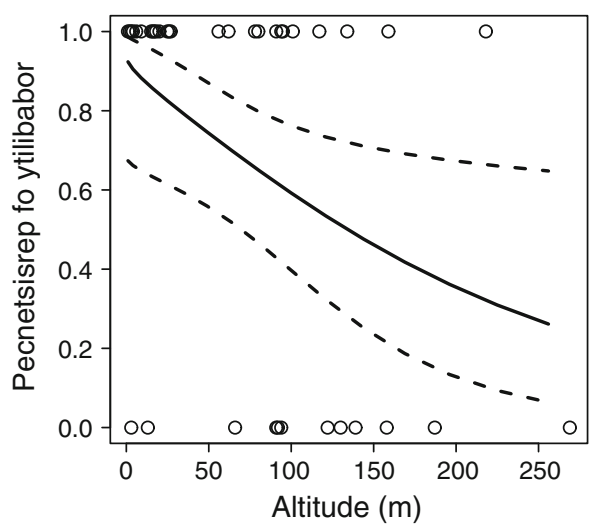

Fig. 3 Predicted effect of altitude in the time period 2011-2012. The estimate is derived from a logistic regression model with altitude as the back-transformed predictor of site persistence. $95 \% \mathrm{CI}$ are shown with dotted lines and the observed survival for lakes over the range of altitudes are shown with open circles. The figure is shown with the full range of altitude values

There was an overall steady decline in the number of breeding pairs that maintained continuous presence over the 21-year time period (Fig. 4), suggesting some unidentified large-scale deterministic factor acting upon the total number breeding pairs in the study area. 


\section{Discussion}

The present 21-year monitoring series of breeding Slavonian Grebe in the northernmost part of its distribution range in Europe showed clear evidence of a decline. The onset of the decline in grebe breeding site occupancy began in 1999, and by 2012, the number of lakes with breeding pairs steeply declined to one-quarter of those lakes that had breeding grebes 13 years earlier. The results support our prediction that lakes with small breeding populations, and to some extent poor environmental conditions (high altitude), have lower persistence, but do not support our prediction that unproductive habitats lead to lower persistence. Persistence of breeding status was predicted well for the majority of the monitoring period by the inclusion of the variable number of breeding pairs, and in the final year, of monitoring by altitude. The number of pairs per site at the onset of monitoring in 1991 was also an excellent representation of the maximum number of pairs per site $(r=0.90)$. Thus, sites with small breeding populations were highly vulnerable to extinction, and the number of breeding pairs in the initial monitoring year explained the majority of the variation in persistence, potentially due to demographic stochastic processes (Caughley 1994), but potentially also environmental factors that might have been underlying the initially low number of pairs. For sites that maintained breeding pairs, it is not clear whether persistence was maintained by site faithfulness by the same individuals over successive breeding seasons, or by replacement of individuals at the same sites via source-sink dynamics, as individuals were not followed in this study. However, evidence from other studies suggests that recruitment from within the regional population, at least in part by returning females, may well play a role in population persistence. Ferguson (1981) found that individuals return to breeding sites in successive breeding seasons

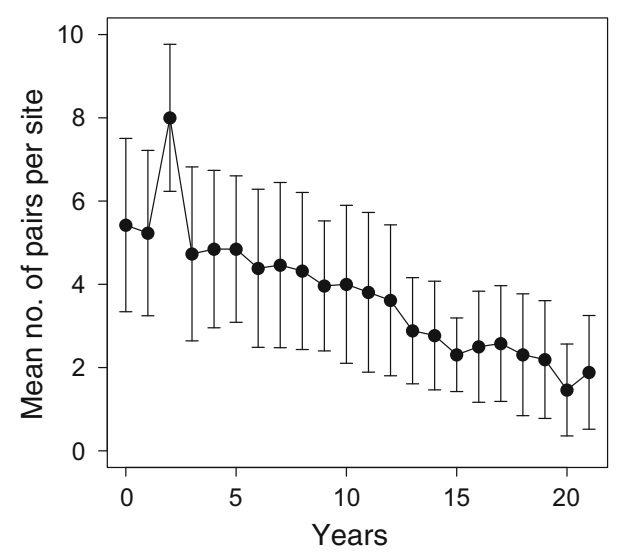

Fig. 4 Mean number of breeding pairs per site and their standard deviations for the 26 sites that still had the presence of breeding pairs in 2012 resulting in a certain level of both lake faithfulness and a wider local area faithfulness, while Fournier and Hines (1999) and Ewing et al. (2013) found a positive association between breeding success and population growth rates in the following year.

The dominant pattern of lake occupancy in our study was not representative for stochastic extinction-re-colonization dynamics according to classical meta-population dynamics. In the framework of a stable metapopulation, the proportion of persistent lakes would be expected to reach a stable steady state (due to a recolonization-extinction balance) the following year after the onset of the monitoring program. In contrast, from an initially high persistence, we observed later in the monitoring period a steep decline, and thus a situation more in line with a "declining population paradigm" due to some deterministic driver (sensu Caughley 1994). Although the data could have provided a false declining trend due to migration to alternative non-monitored lakes, the abundance data (number of pairs per lake) from extant lakes over the entire 21-year period (Fig. 4) clearly show that the declining trend is real. A similar declining trend (which has been ongoing since 1993) has occurred in the Scottish population of Slavonian Grebe (Ewing et al. 2013). While this population forms a southern range boundary for the species and may be expected to be sensitive to other processes, such as range contraction due to climatic warming (Green et al. 2008), low breeding success, which may or may not be related to climate change, appears to be partly responsible for the decline in the Scottish population. Identification of factors that can fully explain the decline have thus far eluded research efforts (Ewing et al. 2013). Reasons for the change in numbers and eastern movement of the Swedish population are also currently unknown (Douhan 1998; Norevik 2014).

The lack of relationship between breeding site persistence and the meteorological variables (air temperature and snow depth) used here as proxies for ice melt dates may have been due to small-scale topographical variation in temperature and catchment effects (Kvambekk and Melvold 2010) not captured in the meteorological data. It would be useful to have better knowledge regarding the extent to which these variables capture the variation in ice melt times at individual lakes. Site persistence was also not correlated with mean winter temperature. However, the drop in persistence between 2010 and 2011 occurred after an exceptionally late ice melt in 2010. The resulting shortening of the breeding season may have resulted in the observed reduced site use the following year. Lagged effects on reproductive performance are apparent in several avian studies and include site avoidance after poor performance (e.g., Stracey and Robinson 2012; Hanssen et al. 2013). As grebes are income breeders (Kuczynski and Paszkowski 2010), the late breeding onset may have 
limited quality of eggs and/or offspring resulting in low productivity. Poor body condition combined with migration to wintering grounds, or non-related but correlated factors in wintering areas, such as poor weather, could have resulted in reduced over-wintering survival (Newton 1998; Golet et al. 2004; Sandvik et al. 2005; Frederiksen et al. 2008). Altitude also negatively affected grebe persistence, but significantly so only between 2011 and 2012. Altitude affects temperature and precipitation and modulates lake productivity and grebe breeding season length (Summers and Mavor 1995). Snow and ice cover delay return dates of individuals breeding at higher latitudes, as they do not return to their breeding sites before there is open water (Fournier and Hines 1999; Øien et al. 2008). Presumably, the variation in ice melt day in this study was not sufficient to prevent grebes from initiating a breeding attempt, apart from in 2010. In 2012, low altitude sites may have been available to most breeders, as site occupancy had become so low. Alternatively, high altitude breeders may have been of poorer quality and so not attempted to breed in 2012.

We found no effects of habitat productivity, as indicated by bedrock, or presence of agricultural grassland indicating eutrophication. The majority of lakes in this study had either neutral or alkaline water characteristics based on bedrock classification, and thus a water chemistry that should not limit fish growth or invertebrate abundance (Eriksson 1986). In addition, aerial insects make up a large proportion of grebe diet and are unlikely to be limited (Fjeldså 1973b; Dillon et al. 2010). In this study, only 19 of the 104 sites were less than 5 ha. This is in contrast to studies from the Baltic and North America that have reported that the majority of sites were less than 5 ha, but in common to earlier studies in northern Norway (Fjeldså 1973c; Faaborg 1976; Summers et al. 2011). The lack of relationship between lake area and breeding number in year $t_{0}$ may be modified by variation in patch quality, making overall lake area a poor predictor of breeding population size (Hanski and Gaggiotti 2004; Lenda and Skórka 2010; Williams 2011). In many of the lakes, overall nesting habitat is patchy and not proportional to lake area. The relationship is further modified by territorial behaviour of the grebe, making high densities unlikely unless vegetation suitable for breeding is abundant (Fjeldså 1973c; Faaborg 1976). We cannot rule out the possibility that the decline is linked to alternate habitat factors other than those we measured in this study, such as fluctuations in availability of food determining breeding success (e.g., Brooks et al. 2012). Currently, no such site level data has been recorded, and it could be beneficial to gather data regarding pertinent habitat factors in the future.

The distribution and numbers of grebe present in the initial monitoring year (1991) suggest a possible recent northern increase in the species range compared to historical accounts gathered between the 1950s and early 1970s (Fjeldså 1980; Strann et al. 2014, Fjeldså pers. comm.). Although the mechanisms behind this shift are unknown, the present study indicates that range expansion further north has probably been limited by climatic conditions, even though there is plenty of available habitat. We are not aware of any published data on the range dynamics at the northern end of the North American range during the same period; however, a study of grebe towards the current North American range edge by Fournier and Hines (1999) shows a clear pattern of population growth with temperature, precipitation and ice-free days. The amount of mixing between the Swedish population and the Norwegian population is unknown, but thought to be little (Fjeldså 1973a). Future investigation of the existing study population's overwintering movements may help determine whether the current change is due to deteriorating conditions at the wintering grounds affecting mortality (e.g., Frederiksen et al. 2008), or migration to alternative breeding sites.

The grebe is suffering decline in both its North American and western European range. In Norway, it now appears to be declining at the northern end of its range. This decline is mostly associated with a low number of pairs at most sites, making the grebe very vulnerable to site extinction, in particular in harsher (higher altitude) environments. In order to say whether this reduction is indicative of a wider decline in the population, it is necessary to expand monitoring to cover a spatial extent that allows estimation of grebe population trends. Optimally, combining spatial data together with data on vital rates, site faithfulness, individual dates of ice melt and habitat characteristics measured at site scale, will allow us to come closer to understanding the main population drivers in the grebe population and whether they are manageable by human intervention.

Acknowledgments We are grateful to Matias Hagtvedt and Jan Heggås for helping to collect data in the field, to Torkild Tveraa for providing meteorological data and the comments from two anonymous referees. Funding was provided by The Norwegian Environment Agency, The County Governor of Troms and The University of Troms $\varnothing-$ Norway's Arctic University.

Open Access This article is distributed under the terms of the Creative Commons Attribution 4.0 International License (http://creativecommons.org/licenses/by/4.0/), which permits unrestricted use, distribution, and reproduction in any medium, provided you give appropriate credit to the original author(s) and the source, provide a link to the Creative Commons license, and indicate if changes were made.

\section{References}

Araújo MB, Luoto M (2007) The importance of biotic interactions for modelling species distributions under climate change. Glob Ecol Biogeogr 16:743-753 
Bird Life International (2004) Birds in Europe: population estimates, trends and conservation status. http://www.birdlife.org/datazone/ userfiles/file/Species/BirdsInEuropeII/BiE2004Sp3640.pdf

Bird Life International (2011) Species factsheet: Podiceps auritus

Borgstrøm R, Museth J, Brittain JE (2010) The brown trout (Salmo trutta) in the lake, Øvre Heimdalsvatn: long-term changes in population dynamics due to exploitation and the invasive species, European minnow (Phoxinus phoxinus). Hydrobiologia 642:81-91

Brooks SJ, Jones VJ, Telford RJ, Appleby PG, Watson E, McGowan S, Benn S (2012) Population trends in the Slavonian grebe Podiceps auritus (L.) and Chironomidae (Diptera) at a Scottish loch. J Paleolimnol 47((4):631-644

Burnham KP, Anderson DR (2002). Model selection and multimodel inference: a practical information-theoretic approach. Springer

Caughley G (1994) Directions in conservation biology. J Anim Ecol 63(2):215-244

Chen I-C, Hill JK, Ohlemüller R, Roy DB, Thomas CD (2011) Rapid range shifts of species associated with high levels of climate warming. Science 333:1024-1026

Cramp S, Simmons KEL, Ferguson-Lees IJ, Gillmor R, Hollom PAD, Hudson R, Nicholson EM, Ogilvie MA, Voous KH, Wattel J (1977) Handbook of the birds of Europe, the Middle East and North Africa. Oxford University Press, London

Davis AJ, Jenkinson LS, Lawton JH, Shorrocks B, Wood S (1998) Making mistakes when predicting shifts in species range in response to global warming. Nature 391:783-786

Dillon IA, Hancock MH, Summers RW (2010) Provisioning of Slavonian Grebe Podiceps auritus chicks at nests in Scotland. Bird Study 57:563-567

Direktoratet for naturforvaltning (2009). Handlingsplan for horndykker Podiceps auritus. Rapport 2009-7

Douhan B (1998) Svarthakedoppingen-en fågel i tilbakegang i Sverige. Vår fågelvräld 57:7-22

Eriksson MO (1986) Reproduction of Black-throated Diver Gavia arctica in relation to fish density in oligotrophic lakes in southwestern Sweden. Ornis Scandinavica 17(3):245-248

Ewing SR, Benn S, Cowie N, Wilson L, Wilson JD (2013) Effects of weather variation on a declining population of Slavonian Grebes Podiceps auritus. J Ornithol 154:995-1006

Faaborg J (1976) Habitat selection and territorial behavior of the small grebes of North Dakota. The Wilson Bulletin 88(3): 390-399

Ferguson RS (1981) Territorial attachment and mate fidelity by horned grebes. Wilson Bulletin 93:560-561

Fjeldså J (1973a) Distribution and geographical variation of the Horned Grebe Podiceps auritus (Linnaeus, 1758). Ornis Scandinavica 4(1):55-86

Fjeldså J (1973b) Feeding and habitat selection of the horned grebe, Podiceps auritus (Aves), in the breeding season. Vidensk. Meddr dansk haturh. Foren 136:57-95

Fjeldså J (1973c) Territory and the regulation of poulation density and recruitment in the horned grebe Podiceps auritus auritus Boje, 1822. Vidensk. Meddr dansk haturh. Foren 136:117-189

Fjeldså J (1980) Forekomst av fugl i vann og våtmarksområder i Salten. Ofoten, Vesterålen og Lofoten

Fjeldså J (2004) The grebes: Podicipedidae. Oxford University Press, USA

Fournier MA, Hines JE (1999). Breeding ecology of the horned grebe Podiceps auritus in subarctic wetlands. Canadian wildlife Service Occasional Paper Number 99:33 s

Fox J (2002). Cox proportional-hazards regression for survival data. appendix to An R and S-PLUS Companion to Applied Regression 1-18. http://socserv.mcmaster.ca/jfox/books/companion/ appendix/Appendix-Cox-Regression.pdf
Frederiksen M, Daunt F, Harris MP, Wanless S (2008) The demographic impact of extreme events: stochastic weather drives survival and population dynamics in a long-lived seabird. J Anim Ecol 77:1020-1029

Gilman SE, Urban MC, Tewksbury J, Gilchrist GW, Holt RD (2010) A framework for community interactions under climate change. Trends Ecol Evol 25:325-331

Godiksen J, Borgstrøm R, Dempson J, Kohler J, Nordeng H, Power M, Stien A, Svenning M-A (2012) Spring climate and summer otolith growth in juvenile Arctic charr, Salvelinus alpinus. Environ Biol Fishes 95:309-321

Golet GH, Schmutz JA, Irons DB, Estes JA (2004) Determinants of reproductive costs in the long-lived black-legged kittiwake: a multiyear experiment. Ecol Monogr 74:353-372

Green RE, Collingham YC, Willis SG, Gregory RD, Smith KW, Huntley B (2008) Performance of climate envelope models in retrodicting recent changes in bird population size from observed climatic change. Biol Lett 4:599-602

Hanski I, Gaggiotti OE (2004). Ecology, genetics, and evolution of metapopulations. Academic Press

Johansen BE (2009) Vegetasjonskart for Norge basert på Landsat TM/ETM + data. North Res Inst, Troms $\varnothing$

Kålås J, Viken $\AA$ (2006). og Bakken T.(red.) 2006. Norsk rødliste 2006

Kuczynski EC, Paszkowski CA (2010) Food-web relations of the Horned Grebe (Podiceps auritus) on constructed ponds in the Peace Parkland, Canada. Wetlands 30:1-11

Kvambekk ÅS, Melvold K (2010) Long-term trends in water temperature and ice cover in the subalpine lake, Øvre Heimdalsvatn, and nearby lakes and rivers. Hydrobiologia 642:47-60

Lawton JH (1993) Range, population abundance and conservation. TREE 8:409-413

Lecis R, Norris K (2003) Habitat correlates of distribution and local population decline of the endemic Sardinian newt Euproctus platycephalus. Biol Conserv 115:303-317

Lecis R, Norris K (2004) Habitat correlates of distribution and local population decline of the endemic Sardinian newt Euproctus platycephalus. Biol Conserv 115:303-317

Lenda M, Skórka P (2010) Patch occupancy, number of individuals and population density of the Marbled White in a changing agricultural landscape. Acta Oecol 36:497-506

McClure CJ, Rolek BW, McDonald K, Hill GE (2012) Climate change and the decline of a once common bird. Ecol evol 2:370-378

Moran EV, Alexander JM (2014) Evolutionary responses to global change: lessons from invasive species. Ecol Lett 17:637-649

Newson SE, Woodburn RJ, Noble DG, Baillie SR, Gregory RD (2005) Evaluating the Breeding Bird Survey for producing national population size and density estimates: capsule The BBS has potential for producing better estimates of habitat-specific densities and population sizes for many UK bird populations than those available previously. Bird Study 52:42-54

Newton I (1998). Population limitation in birds. Academic Pr

Norevik G (2014) Horned Grebe, Podiceps auritus and Red-necked Grebe Podiceps grisegena in Sweden 2011-results from a national survey. Ornis Svecica 24:81-98

Øien IJ, Aarvak T (2008) Horndykkeren i Norg-truet art i frammarsj? Vår fuglefauna 31:20-27

Øien IJ, Aarvak T (2009). Kunnskspasstatus og forslag til nasjonal handlingsplan for horndykker

Øien IJ, Aarverk T, Reinsborg T (2008) Horndykkeren i Norge - truet art i frammarsj ? Vår fuglefauna 31(1):20-27

Pöysä H, Rintala J, Lehikoinen A, Väisänen RA (2013) The importance of hunting pressure, habitat preference and life history for population trends of breeding waterbirds in Finland. Eur J Wildl Res 59:245-256 
R Core Team (2014) A language and environment for statistical computing. R Foundation for Statistical Computing, Vienna, Austria. URL http://www.R-project.org/

Rius M, Darling JA (2014) How important is intraspecific genetic admixture to the success of colonising populations? Trends Ecol Evol 29:233-242

Sandvik H, Erikstad KE, Barrett RT, Yoccoz NG (2005) The effect of climate on adult survival in five species of North Atlantic seabirds. J Anim Ecol 74:817-831

Sexton JP, McIntyre PJ, Angert AL, Rice KJ (2009) Evolution and ecology of species range limits. Annu Rev Ecol Evol Syst 40:415-436

Sonntag N, Garthe S, Adler S (2009) A freshwater species wintering in a brackish environment: habitat selection and diet of Slavonian grebes in the southern Baltic Sea. Estuar Coast Shelf Sci 84:186-194

Stien J, Ims RA (2015) Management decisions and knowledge gaps: learning by doing in a case of declining population of Slavonian grebe (Podiceps auritus). J Wildl Biol 21(1):44-50

Stracey CM, Robinson SK (2012) Are urban habitats ecological traps for a native songbird? Season-long productivity, apparent survival, and site fidelity in urban and rural habitats. J Avian Biol 43:50-60. doi:10.1111/j.1600-048X.2011.05520.x

Strann KB, Frivoll V (2010). Overvåking av hekkende horndykker i Troms 2009. NINA Minrapport 290. 15 pages
Strann KB, Frivoll V, Heggås J, Hagtvedt M (2014). Overvåking av hekkende horndykker i Troms 2013. Minirapport 485. 19 pages

Summers R, Mavor R (1995) Occupation patterns of lochs by Slavonian Grebes in Scotland. Scottish Birds 18:65-70

Summers RW, Mavor RA, Hogg S, Harriman R (2011) Lake characteristics and their selection by breeding Slavonian Grebes Podiceps auritus in Scotland. Bird Study 58:349-356

Thomas CD (2010) Climate, climate change and range boundaries. Divers Distrib 16:488-495

Traill LW, Bradshaw CJ, Brook BW (2007) Minimum viable population size: a meta-analysis of 30 years of published estimates. Biol Conserv 139:159-166

Ulfvens J (1988) Nest characteristics and nest survival in the Horned Grebe Podiceps auritus and great crested grebe Podiceps cristatus in a Finnish archipelago. Ann Zool Fenn 25:293-298

van Swaay CA, Nowicki P, Settele J, van Strien AJ (2008) Butterfly monitoring in Europe: methods, applications and perspectives. Biodivers Conserv 17:3455-3469

White TCR (2008) The role of food, weather and climate in limiting the abundance of animals. Biol Rev 83:227-248

Williams MR (2011) Habitat resources, remnant vegetation condition and area determine distribution patterns and abundance of butterflies and day-flying moths in a fragmented urban landscape, south-west Western Australia. J Insect Conserv 15:37-54 